\title{
原著
}

\section{水酸化カルシウムを重合触媒とした Cyanoacrylate-}

\section{methacrylate 裂溝 Sealant の 1 力年臨地試験}

\begin{tabular}{|c|c|c|c|c|c|c|c|c|}
\hline A. 堀 & 井 & 欣 & 一, $^{x}$ & 境 & & 脩； & B. 丹 羽 輝 & 男 ${ }^{x}$, \\
\hline 坪 & 根 & 哲 & 郎, & 吉 & 田 太 & - & 山田紘 & 杵 \\
\hline$山$ & 根 & 健 & 久; & C. 大 & 西 正 & 男 ${ }^{x}$, & 岡田昭五 & 郎， \\
\hline 公 & & & 宏; & D. 美 & 濃 口 & 玄 $^{x}$, & 松 & 昌, \\
\hline 塩 & 田 & & 覚, & 五 & 嘉 & 明， & 系 井 昭 & 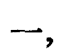 \\
\hline 圤 & 井 & 宏 & 雄, & 塚 & 本 欣 & 幸， & 飯 塚 忠 & \\
\hline $\mathrm{E}$. & 野 & 尊 & 睦“, & 古 & 川 哲 & 夫, & 大野暉八 & \\
\hline & 井 & 正 & 義, & 山 & 田重 & 樹; & F. 柳 生 嘉 & , \\
\hline & 田 & 義 & 勝, & 宫 & 脇 美 智 & 子, & 佐々 木 & \\
\hline & 村 & 博 & 正, & 口 & 岡 芳 & 男, & 上 田 & \\
\hline 原 & & 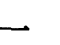 & 弘, & 中 & 尾 俊 & - & & \\
\hline
\end{tabular}

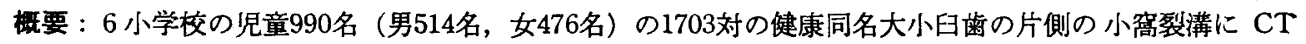
処置をし, 他側を対照歯とし, 半年後及び 1 年後にう蝕の有無を検查した。各小学校はそれぞれ異つた大学 研究機関が，カリブレーションされた封鎖技法とう蝕診断規準で，分担したものである。CT 処置と称する 封鎖阂は Ethyl-2-Cyanoacrylate monomer と Polymethyl metacrylate に水酸化カルシウムを混合したを ので，術前小窩裂淦を燐酸で前処理した菌にこれを適用した。

対照歯に対して，CT 処置は半年後で $60.7 \% ， 1$ 年後で $38.3 \%$ の蝕発生率の抑制をもたらし，この值は それぞれ統計的に有意であつた。同じ期間に CT が小窩裂满内に残存していた率はそれぞれ，76.7\%と52.6 \%であつた。

小箁と裂溝の状態を変えて，う蝕の発生を予防 する方法として， 硝酸銀 ${ }^{12)}$ ， フッ化アンモニア

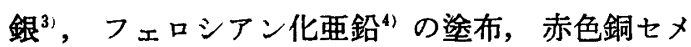
ントで裂溝の封鎖，ニトロセルローズによる被膜 法5), あるいは $\mathrm{Hyatt}^{6 / 7)}$ の行なつた裂溝部の最少 笨囲の開削 (Odontotomy) とアマルガム充填等 が，多くの研究者によつて発表されている。最近 になつて高分子化学の進歩に伴い現われた接着剤 がこの目的に使用されだした。この技術は予防菌 科学界では特に注目されている。その理由として
考えられるのは 飲料水のフッ素の予防効果が平滑 面に有効であるが，小窝裂溝にそれ程の効力をも たないし，またフッ素添加茵磨剂を使つても，小 窩裂溝での抑制率は平滑面に 現われるむのよりは るかに低いこと等の事実であろうと思われる。

すでに1955年 Buonocore ${ }^{8)}$ は methylmethacrylate 即重レジンを小䆟裂瑇の 封鎖に 使用したの であるが，最近脚光をあびている封鎖材料は1955 年 Eastman 社で作られた強力な万能接着剂 $\mathrm{Me}$ thyl-2-Cyanoacrylate (Eastman 910) の出現に

×印は各機関代表者，A-E は機関記号（本文参隔）を意味する

昭和48年 6 月 15 日受付 
始まる ${ }^{9)}$ 。このものは微量の水分, 例えば空気 中, したがつて口腔内水蒸気によつて重合するも のである。ただしロ腔内環境でエナメル質によく 接合するものはないが，これをあらかじめ酸処理 するときは，Methyl cyanoacrylate を含む化合 物 (Cueto and Bunocore, 1967 ${ }^{10)}$ ) は小裔裂溝を 封鎖するのに十分役に立つことが知られている。 また竹内と木津 $\left(1966^{11}\right)$ も同じ目的に alkylcya noacrylate と Methylmethacrylate の混合物で, 小窝裂溝を封鎖し，9 カ月の臨地実験で有効であ つたといつている。(Takeuchi et al, 1966 ${ }^{12)}$ )

ついで1967年 Gwinnett and Matsui ${ }^{91}$ は封鎖前 に燐酸でエナメル質表面を前処理すると，モノマ 一のエナメル稜柱内への侵入が良好となり，重合 後は禾状の tag-like extensions がエナメル質内 にく、込み，接触面の拡大とともに，接着性は非 常によくなることを知つた。Buonocore, Matsui and Gwinnett ${ }^{13)}$ (1968) は, 酸処理によつてエナ メル表面の物理化学的性状が変化し, その結果 wetability の改善されることを発見し，これが接 着性をよくすると述べている。

最近 Buonocore ${ }^{14)}$ は $50 \%$ 燐酸で前処理した後, Bowen's レジン, methylmethacrylate および monoethylether hydroquinone の混合液に硬化促 進剂と紫外線によつて小窩裂溝内での 重合を短時 間で得て，良好な臨床結果を得ている。

小窩裂溝の封鎖技術は接着性よく，重合条件の control ができる sealant を使用することである と思われるが, その効果は広範囲の臨床実験で決 められることである。

この報告は 昭和44年 4 月に 6 研究機関（方法の 項参照) が 6 つの小学校 $1 \sim 6$ 年生 990 名を対象 として，咬合面の小窩裂溝に 対して，松井 ${ }^{15)} の$ 考案になる Ethyl-2-Cyanoacrylate モノマーに Polymethylmethacrylate と重合触媒剤である水 酸化カルシウムを混合したものを練和し，それを Sealant として使用するもののう蝕予防効果を検 討した 結果である。

\section{方 法}

臨床実験はそれぞれ独立した 6 研究機関 $〔(\mathrm{~A})$
新潟大学歯学部，予防歯科学教室（代表堀井欣一 教授)，（B）日本歯科大学衛生学教室（代表丹羽 輝男教授)，(C) 東京医科歯科大学歯学部，予防 歯科学教室(代表大西正男教授)，(D) 京郡大学医 学部，口腔外科学教室 (代表美濃口玄教授)，（E） 大阪医科大学, 口腔外科学教室（代表小野尊睦教 授)，（F）大阪歯科大学口腔衛生学教室（代表柳 生嘉雄教授) でう蝕検查と封鎖手技の統一した力 リブレーションのもとに 6 小学校児童 1249 名に対 して実施されたものである。但し実験中観察が完 了しなかつたものを除くと，990名(男514，女476) で，小学校名，対象学年等は表 1 の通りである。

表 1 被験者, 実験終了者

男 女
A. 新潟市新潟大学付属小学校
221名 $(116,105)$
B. 東京都泰明小学校 $(1 \sim 5$ 年 $)$
130名 ( 73，57)

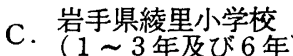
139名( 65,74$)$
D. 滋賀県高鳥小学校 $(1 \sim 6$ 年 $) \quad 264$ 名 $(136,128)$
E. 京都市山之内小学校(4６年) 119名( 65，54)
F. 尼崎市御堂小学校 ( 2 年) 117 名 $(59,58)$

990名 $(514 ， 476)$

A-Fは研究機関名の略称である。本文参照

実験は左右同名歯の 0 状態（後述）である 歯に ついて，そのどちらかの小窩あるいは裂溝を封鎖 し，のこりの歯を対照歯とした。実験に使われた 歯の右左側により人数と歯数を分けると右型は

表 2

\begin{tabular}{|c|c|c|c|c|c|c|c|}
\hline & 1 & 2 & 3 & 4 & 5 & 6 & 合 計 \\
\hline 7 & - & - & - & - & 4 & 4 & 8 \\
\hline$\underline{6}$ & 130 & 138 & 256 & 113 & 60 & - & 697 \\
\hline$\underline{\mathbf{5}}$ & - & - & 3 & 36 & 54 & - & 93 \\
\hline$\underline{4}$ & - & 2 & 10 & 79 & 106 & - & 197 \\
\hline$\overline{4}$ & 1 & - & 17 & 69 & 89 & - & 176 \\
\hline$\overline{5}$ & 3 & - & 10 & 22 & 40 & - & 75 \\
\hline$\overline{6}$ & 110 & 89 & 148 & 57 & 28 & - & 432 \\
\hline$\overline{7}$ & - & - & - & 5 & 12 & 8 & 25 \\
\hline 合 計 & 244 & 229 & 444 & 381 & 393 & 12 & $1703 x$ \\
\hline
\end{tabular}


536名，958歯，左型は454名，744歯であつた。被 験者の年齢から実験に最も多く使われた歯は第一 大臼菌であつた。

実験開始前の口腔診査で視診と No. 2 メリケン 針の尖端による触診により次のように分類した。 Fは処置歯，Mは抜去歯，Dは即時充塡あるいは 抜歯を要するう蝕をもつ歯である。これら以外の 歯を実験対象歯とし，これをOで表わした。した がつてO歯は小窩裂㸺に着色なく探針に sticky feeling のないもの $\left(\mathrm{O}_{0}\right)$, 着色があるが探針に sticky feeling のないもの $\left(\mathrm{O}_{1}\right)$, および着色の有 無にかかわらず sticky feeling があるが充填を即 時必要としないもの $\left(\mathrm{O}_{2}\right)$ ，の 3 種類となる。そし て上述の如く左右の同名歯が○の状態であるとき これが実験対象歯となつた。表 2 の歯数は封鎖処 置をうけた歯の数で，これと同名同数の歯が control 歯として観察されている。一対の同名歯のう ちどちらかの歯を封鎖するのであるが，そのとき はできるだけ 左右同数になるように被験者を配分 した結果が上記の右型左型の数である。

実験に使用した Sealant は, Ethyl-2-Cyanoacrylate と Polymethylmetacrylate (PMM) を使 用し, 重合触媒に水酸化カルシウムを加え, 硬化 速度を一定に調節し封鎖技術を容易にしている。 具体的には
1. 液体…Ethyl-2-Cyanoacrylate monomer

2. 粉末…PMM および硬化剂（水酸化カル シウム)

この 1 と 2 の等容量を 使用直前混合用アセテート シートの上で練和し，酸処理をした小窩あるいは 裂溝に適用した。硬化は非常に速やかであつた。 選ばれた歯の咬合面はロビンソンブラシと研磨ぺ ーストで清掃され，水洗後歯面を簡単に乾燥す る。簡易防湿下で，この歯の咬合面に表面処理液 を塗布し， 2 分後洗い落す。処理液は $30 \sim 40 \%$ 燐酸 溶液に金属塩を添加し， $\mathrm{pH}$ 調整したものである。

このように処置された 学童を半年後と 1 年後の 2 回追跡診查し，小窩裂溝の状態を最初のときと 同じ規準で記載し，この 結果を CT 処置と対照 歯の間で比較した。追跡診査で得られる 歯の記号 は O. D. F で， (D+F/O+D+F $) \times 100$ をこの 期間のら蝕発生率 $\left(\Delta \mathrm{E}\right.$ と $\left.\Delta \mathrm{E}_{0}\right)$ とした。これを $\mathrm{CT}$ 処置 $(\Delta \mathrm{E})$ と対照歯 $\left(\Delta \mathrm{E}_{0}\right)$ で比較し，CTによ る抑制率 $\left(\frac{\Delta \mathrm{E}_{0}-\Delta \mathrm{E}}{\Delta \mathrm{E}_{0}} \times 100\right)$ で現わし，差の有意性 を検定した。実験数の少く統計処理の困難な群に は (一)，有意水準 $5 \%$ 以上を○，5\%以下 $1 \%$ ま でを $\times, 1 \%$ 以のものを $\times$ ，で表わした。CT 処置をした歯だけに観察される状態は, Sealant が残つているかあるいは脱落したかで，この状態

表 3

\begin{tabular}{|c|c|c|c|c|c|c|c|c|c|c|}
\hline & & 7 & $\underline{6}$ & $\underline{5}$ & $\underline{4}$ & $\overline{7}$ & $\overline{6}$ & $\overline{5}$ & $\overline{4}$ & 合 \\
\hline \multirow[b]{2}{*}{ 半 } & $\mathrm{CT}$ & $0 / 8$ & $28 / 697$ & $1 / 93$ & $1 / 197$ & $1 / 25$ & $45 / 432$ & $1 / 75$ & $2 / 176$ & $79 / 1703$ \\
\hline & (\%) & 0 & 4.0 & 1.1 & 0.5 & 4.0 & 10.4 & 1.3 & 1.1 & 4.9 \\
\hline \multirow{4}{*}{ 年 } & Control & $1 / 8$ & $56 / 697$ & $6 / 9$ & $12 / 197$ & $7 / 25$ & $102 / 432$ & $10 / 75$ & $7 / 176$ & $201 / 1703$ \\
\hline & $(\%)$ & 12.5 & 8.0 & 6.5 & 6.1 & 28.0 & 23.6 & 13.3 & 3.4 & 11.8 \\
\hline & 有意差検定 & $(-)$ & $(x \times)$ & (O) & $(x \times)$ & $(x)$ & $(x \times)$ & $(x)$ & $(0)$ & \\
\hline & 抑 制 率(\%) & 100 & 50 & 83 & 91.8 & 92.9 & 55.9 & 90.2 & 67.6 & 60.7 \\
\hline \multirow{4}{*}{ - } & CT & $2 / 8$ & $108 / 697$ & $6 / 93$ & $14 / 197$ & $2 / 25$ & $113 / 432$ & $5 / 75$ & $8 / 176$ & $258 / 1703$ \\
\hline & (\%) & 25 & 15.5 & 6.5 & 7.1 & 8.0 & 26.2 & 6.7 & 4.5 & 15.1 \\
\hline & Control & $2 / 8$ & $148 / 697$ & $14 / 93$ & $27 / 197$ & $9 / 25$ & $187 / 432$ & $16 / 75$ & $15 / 176$ & $418 / 1703$ \\
\hline & (\%) & 25 & 21.2 & 15.1 & 13.7 & 36 & 43.3 & 21.3 & 8.5 & 24.5 \\
\hline \multirow[t]{2}{*}{ 年 } & 有意差検定 & $(-)$ & $(x \times)$ & (O) & $(x)$ & $(x)$ & $(x \times)$ & $(x)$ & (O) & \\
\hline & 抑 制 率(\%) & 0 & 26.9 & 57.0 & 48.2 & 77.8 & 39.5 & 68.5 & 47.1 & 38.3 \\
\hline
\end{tabular}

分母は被験歯数，分子はう蝕䍜患歯数を表わす。 
表 4

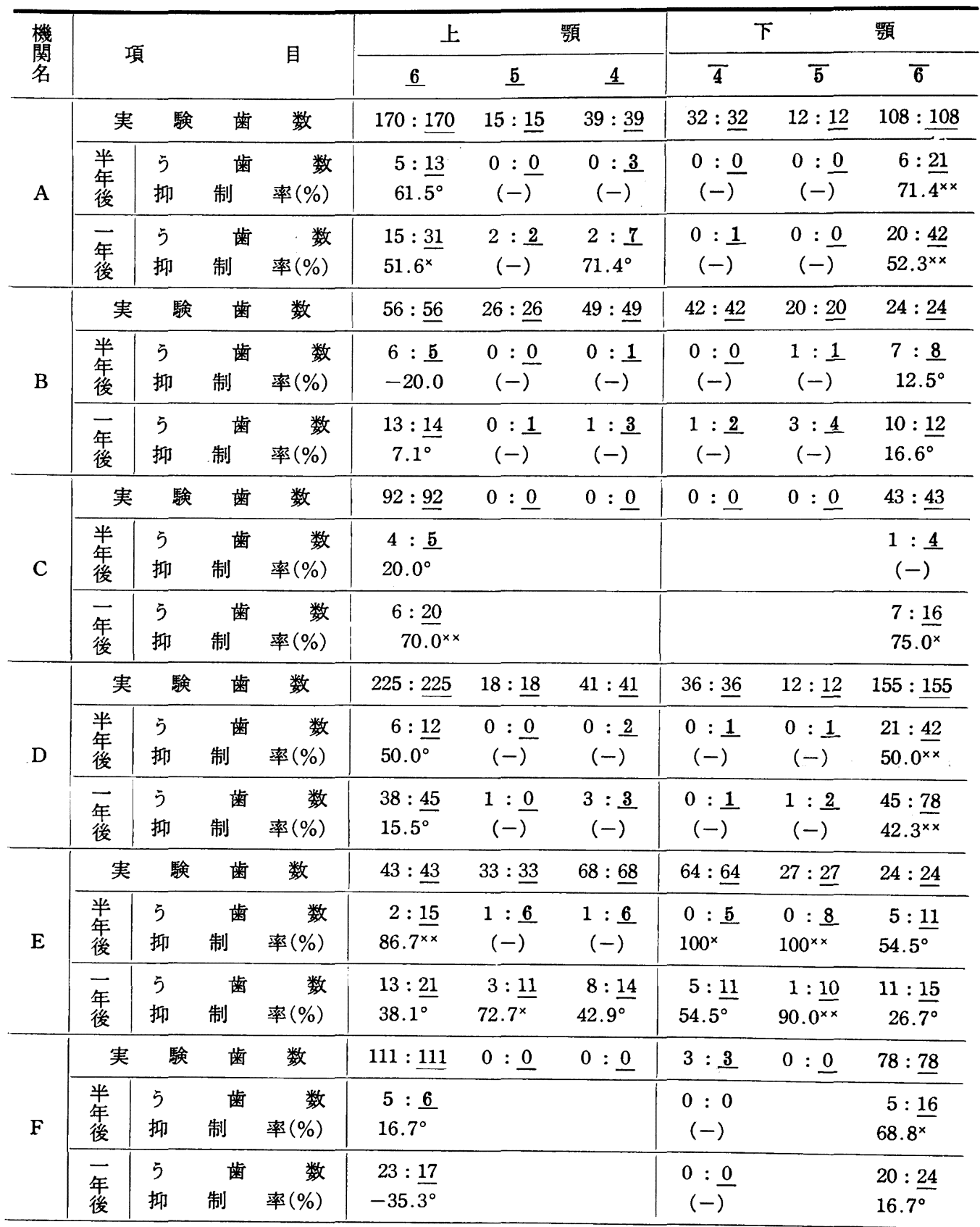

記号の説明 : アンダーラインのある数字はコントロール群のものである。

抑制率（\%）のところの（一）印は数字が検定に不足するもの，

○をつけた数字は危険率 $5 \%$ 以上で有意でないもの，

× は $5 \%$ 以下 $1 \%$ 以上で，××は $1 \%$ 以下で有意であったものを意味する。 


\begin{tabular}{|c|c|c|c|c|c|c|c|c|c|}
\hline & 7 & $\underline{6}$ & $\underline{5}$ & $\underline{4}$ & $\overline{7}$ & $\overline{6}$ & $\overline{5}$ & $\overline{4}$ & 平 \\
\hline 半 年 後 & $8 / 8$ & $538 / 697$ & $80 / 93$ & $177 / 197$ & $20 / 25$ & $262 / 432$ & $67 / 75$ & $155 / 176$ & $1307 / 1703$ \\
\hline 接着 性(\%) & 100 & 77.2 & 86.2 & 89.8 & 80.0 & 60.7 & 89.5 & 87.9 & 76.7 \\
\hline 1 年 後 & $5 / 8$ & $341 / 697$ & $66 / 93$ & $145 / 197$ & $11 / 25$ & $139 / 432$ & $54 / 75$ & $134 / 176$ & $895 / 1703$ \\
\hline 接着性(\%) & 62.5 & 48.9 & 71.3 & 73.5 & 44.0 & 32.2 & 72.4 & 75.9 & 52.9 \\
\hline
\end{tabular}

分母は処置歯数, 分子は CT の残存している歯数

をそれぞれ OK とGで記載した。接着性は $(\mathrm{OK} /$ $\mathrm{OK}+\mathrm{G}) \times 100$ で表わした。

\section{成 績}

実験が 1 年間行なわれた 被験歯は 3406 歯であつ た。

6 機関の成績を歯種を区別せずに 合計すると， CT によるう蝕発生の抑制率は半年で $60.7 \%, 1$ 年間で $38.3 \%$ で, CT 処置群と 非処置群に現われ たう蝕発生率の差は $1 \%$ 以下の危険率で有意であ つた。（表 3 ）しかし各機関毎にこれを観察すると きは相当の開きがあつた。被検歯の少、第 2 大臼 歯を除いた残りの歯で見られた抑制率を研究機関 毎に統計したのが第 4 表である。歯の種類で観察 すると半年の成績で最も有効であつたのは, 最高 Z $(100 \%)$, 最低 $6(50.0 \%) て ゙ ， 1$ 年の成績で は最高 $\overline{7}(77.8 \%)$, 最低?（0\%）であつた。

接着性は平均半年で76.7\%, 1 年で $52.6 \%$ に低

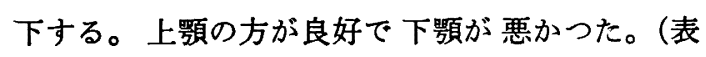
5)

\section{考察}

全処置霜をあわせた結果， CT 処置歯と非処置 歯に現われたう蝕発生率の 差は $1 \%$ 以下の危険率 で有意であったことは，CT による小裔裂溝処置 は予防効果のあることを示すものと考察する。そ の効果は歯種によつて同じではなかつたが, 平均 抑制率は半年で $60.7 \%, 1$ 年で $38.3 \%$ あつた。 Sealant が 1 年の方が抑制率が悪くなる説明は封 鎖物質の脱落が増加することが最大の原因と思わ れるが，接着性は平均半年で $76.7 \% ， 1$ 年で 52.6 \%に低下している。抑制率と接着性の数字はこの 方法による予防技術を公衆衛生化する場合の有力 な基礎資料となると思う。しかしこれを各機関毎
に細部にわたつて考察すると，関倸は簡単でなか つた。しかし全機関の成績を半年と 1 年で合計し たときは Sealant が接着していることがう蝕を予 防していると考えてよいもののようであった。

今回の実験で, 処置中に遭遇した臨床経験は接 着性を高める上に，またこの技術を公衆衛生的に 利用する場合の参考になると思う。

機関から出された意見をまとめてみると，硬化 時間がはやすぎたために操作が 困難であつたこと である。その理由として挙げられたものは実施が 高温の初夏であつたことであるが，これは Ca $(\mathrm{OH})_{2}$ の添加量を少くすることで解決できると 考えられる。次にモノマーの反応性が Lot 番号 によつて違つていたことが指摘されたが，混合用 のアセテート板が水分を含み，その量が必ずしも 一定していなかつたこと，また表面に附着してい る微細な污染物も重合速度に影響を及ぼしたので はないかと推定されている。次に封鎖操作の容易 な下顎第一大鼠に接着性が悪かつた事実に対し て，実験者の多くはこの歯は見やすく判定が容易 であつたためとの意見を述べた。今回の Sealant は着色がほどこされなかつたので脱落の判定が困 難であつたことがその根拠となつている。

\section{謝辞}

本研究に対して武田薬品工業株式会社より研究遂行に 多大の援助を受けたことを深謝するとともに公衆衛生の 基碳的研究に対する同社の愁意に敬意を表す。

また本研究の実施にあたり, 吉岡節子, 小杉成子, 阿 部満和子 $(\mathrm{A})$; 高橋满子 (B); 村上淑子, 德增暁美, 牧 野節子 (C); 伊藤良美, 桶口京子, 秋岡久実子 (D); 熊 木郁子(E)の菌科衛生士, 寺島美和子 (F) 薬棛師の御協 カを得たことを感䫀します。 


\section{文献}

1) Klein, W. Knutson, J. W.: Studies on dental caries. Effect of ammoniacal silver nitrate on caries in first permanent molar. J. A. D. A., 29 : 1420-1426, 1942.

2) Miller, J.: Clinical investigations in preventive dentistry. Brit. D. J., 91 : 92- , 1951.

3）山賀礼一：フッ化アンモニア銀の作用機序とそ の使用方法について，歯科評論，328号， 1-8, 1970.

4) Ast, D. B., Bushed, A., Chase, H. C.: A clinical study of caries prophylaxis with zinc chloride and potassium ferocyanide. J. A. D. A., 41 : 437-442, 1950.

5) Gore, J. T.: Etiology of Dental Caries. Enamel immunization experiments, J. A. D. A., 26 : 958-959, 1939.

6) Hyatt, T. P.: Prophylactic odontotomy. Dent. Cos., 65 : 623- , 1923.

7) Hyatt, T. P. : Prophylactic odontotomy. The cutting into the tooth for the prevention of disease. Dent. Cos., 65 : 234-241, 1923.

8) Buonocore, M. G. : Simple method of increasing the adhesion of acrylic filling materials to enamel surfaces. J. dent. Res. $34: 849-$
853, 1955.

9) Gwinnett, A. J. and Matsui, A.: A study of enamel adhesives. The physical relationship between enamel and adhesive. Archs oral Biol. 12 : 1615-1620, 1967.

10) Cueto, E. and Buonocore, M. G. : Adhesive sealing for pits and fissures for caries prevention. I. A. D. R. 43 rd Meeting Abstr. No. 400, 1965.

11) Takeuchi, M. and Kizu, T.: Sealing of the pit and fissure with resin adhesive. I, Results of sealing on extracted teeth. Bull. Tokyo Dent. Coll., 7 : 50-59, 1966.

12) Takeuchi, M. and Kizu, T.: Sealing of the pit and fissure with resin adhesive. II, Results of nine months' filled work, an investigation of electric conductivity of teeth. Bull. Tokyo Dent. Coll., $7: 60-71,1966$.

13) Buonocore, M. G., Matsui, A. and Gwinnett, A. J. : Penetration of resin dental materials into enamel surfaces with reference to bonding. Archs oral Biol., $13: 61-70,1968$.

14) Buonocore, M. G. : J. Amer. dent. Ass., $80: 324-\quad, 1970$.

15）松井昌 : 執筆中.

Abstract : One Year Field Trial of a Fissure sealant Composed by Cyanoacrylate-polymethyl Methacrylate and Calcium Hydroxide Catalyst, A. Kin-ichi HORII, Osamu SAKAI, B. Teruo NIWA, Tetsuro TSUBONE, Taichi YOSIDA, Hiromitsu YAMADA, Takehisa YAMANE, C. Masao ONISI, Shogoro OKADA, Hiroshi TANI, D. Gen MINOGUCHI, Akira MATSUI, Satoru SHIOTA, Yoshiaki TANI, Shoichi ITOI, Hiroo HORII, Kinko TSUKAMOTO, Tadahiko IIZUKA, E. Takatoki ONO, Tetsuo FURUKAWA, Kihachiro ONO, Masayoshi FUKUI, Shigeki YAMADA, F. Yoshio YAGIU, Yoshikatsu MASUDA, Michiko MIYAWAKI, Hiroshi SASAKI, Hiromasa MATSUMURA, Yoshio YOSHIOKA, Itsuo UEDA, Kazuhiro HARA, Schunichi NAKAO Thirty two collaborators belonging to six different institutions, Niigata Univ., Sch. Dent., (A), Nippon Dent. Coll. (B), Tokyo Med. Dent. Univ., Sch. Dent. (C), Kyoto Univ., Sch. Med. (D), Osaka Med. Coll. (E), Osaka Dent. Coll. (F)., applied cyanoacrylate-polymethyl methacrylate sealant to the pits and fissures of 1703 occlusal surfaces of 990 school children of 6 schools and the same numbers of opposite surfaces were left untouched as. a control. The different criteria regarding the caries and the sealing procedure among the various collaborators were well coordinated before the trial. Cyanoacrylate monomer and polymethyl methacrylate containing a suitable amount of calcium hydroxide were mixed on an acetate sheet and then the mixture was applied to an occlusal surface preconditioned by approximately $40 \%$ phosphoric acid. The caries reduction figure was obtained in comparison with different incidences of cavities produced on both the test and control teeth. The reductions in the caries incidence, $60.7 \%$ after 6 months and $38.3 \%$ after one yeat produced statistically significant differences. Retention figures of the sealants were $76.7 \%$ after 6 months and $52.6 \%$ after 12 months respectively. 